\title{
Targeting Metal Homeostasis as a Therapeutic Strategy for Alzheimer's Disease
}

\author{
Antonietta Vilella ${ }^{1 *} \bullet$ Eleonora Daini ${ }^{1 *} \bullet$ Chiara A. De Benedictis ${ }^{2 *} \bullet$ \\ Andreas M. Grabrucker $2,3,4$ \\ ${ }^{1}$ Department of Biomedical, Metabolic and Neural Sciences, University of Modena and \\ Reggio Emilia, Modena, Italy; ${ }^{2}$ Cellular Neurobiology and Neuro-Nanotechnology Lab, \\ Department of Biological Sciences, University of Limerick, Limerick, Ireland; ${ }^{3}$ Bernal \\ Institute, University of Limerick, Limerick, Ireland; ${ }^{4}$ Health Research Institute (HRI), \\ University of Limerick, Limerick, Ireland
}

Author for correspondence: Andreas M. Grabrucker, Cellular Neurobiology and Neuro-Nanotechnology Lab, Department of Biological Sciences, Bernal Institute of University of Limerick, Limerick, Ireland. Email: andreas.grabrucker@ul.ie

Doi: https://doi.org/10.36255/exonpublications.alzheimersdisease.2020.ch5

\begin{abstract}
Trace metals play an important role in the pathophysiology of amyloid precursor protein, amyloid beta, and tau, the key molecules involved in Alzheimer's disease. Altering trace metal concentrations in the brain has been explored as a therapeutic strategy for Alzheimer's disease. It is not only the accumulation of metals that drives amyloid beta aggregation, but also the lack of sufficient trace metals for other biological processes created through sequestration by amyloid beta that affects brain health and function. Thus, balancing metal levels to achieve therapeutic effects is an intricate process. This chapter summarizes the role of trace metals in Alzheimer's disease and highlights the preclinical and clinical studies targeting metal homeostasis in animal models and humans. It further discusses recent developments in pharmacological approaches targeting metals in Alzheimer's disease and provides an outlook on possible future treatments based on current translational research, for example, nanomedicine.
\end{abstract}

*These authors contributed equally.

In: Alzheimer's Disease: Drug Discovery. Huang X (Editor). Exon Publications, Brisbane, Australia. ISBN: 978-0-6450017-0-9; Doi: https://doi.org/10.36255/exonpublications.alzheimersdisease.2020 Copyright: The Authors.

License: This open access article is licenced under Creative Commons Attribution-NonCommercial 4.0 International (CC BY-NC 4.0) https://creativecommons.org/licenses/by-nc/4.0/ 
Keywords: ionophores; metal protein attenuating compounds; polymeric nanoparticles; trace metals in Alzheimer's disease; zinc metallochaperones

\section{INTRODUCTION}

Over the last decade, the literature covering the roles of metals in biological systems has increased considerably. Metallobiology has become a useful tool in investigating the connection between metals, metalloproteins, and neurodegenerative diseases and other disorders of the central nervous system (CNS). The primary risk factor for Alzheimer's Disease (AD) is aging $(1,2)$. However, evidence shows that dysregulation of trace metals such as copper $(\mathrm{Cu})$, zinc ( $\mathrm{Zn})$, iron ( $\mathrm{Fe})$, aluminum (Al), manganese $(\mathrm{Mn})$, and other elements such as lead $(\mathrm{Pb})$ and cadmium $(\mathrm{Cd})$ is also associated with $\mathrm{AD}(3)$. Fe, $\mathrm{Zn}, \mathrm{Cu}$, and $\mathrm{Mn}$ are essential for various biochemical and physiological processes in humans, playing roles in structural and regulatory functions in proteins, cellular signaling pathways, and oxygen transport. In the human body, the distribution of metals is different for each organ. For example, in the human brain, the most abundant trace metal is iron, mostly found as heme iron (iron bound to hemoglobin in red blood cells). Iron is essential not only for the transport of oxygen but also as a cofactor for a series of enzymes that play a role in the synthesis of neurotransmitters such as tryptophan hydroxylase and tyrosine hydroxylase $(4,5)$. Additionally, iron has several functions in the CNS including the regulation of synaptic plasticity (6), the myelination of neuronal axons (7), and the regulation of the neuronal energy status (8). Zinc is the second most copious trace element in the human brain (9). Like iron, zinc is a modulator of synaptic plasticity. In addition to this, it can regulate neurogenesis, neuronal migration, and differentiation, and plays a role in neurotransmission (10-12). Zinc is a fundamental structural and catalytic component of proteins, acting as a cofactor for over 300 enzymes. It also gives stability to various transcription factors. Finally, zinc has neuroprotective functions, and can protect against oxidative stress $(13,14)$. Copper is the third most prevalent trace metal in the brain. Like zinc, copper acts as a cofactor for a series of enzymes and plays a vital role in the biosynthesis of neurotransmitters (15). Manganese is a cofactor for several enzymes, including glutamine synthetase, pyruvate carboxylase, arginase, MnSOD, and protein serine/threonine phosphatase- 1 . Mn is also involved in a series of Mn-sensitive pathways, such as the ATM-p53 pathway (16).

Thus, trace metals are involved in enzyme activation, catalysis, regulation of gene expression, and protection against reactive oxygen species (ROS). Therefore, they are fundamental to appropriate brain growth, development, and function. The homeostasis of these charged elements is tightly regulated at the blood-brain barrier (BBB); metal ions are actively transported across the BBB by several transport proteins. Any disruption of metal balance, which can be caused by impairments in the processes of absorption, distribution, and excretion, or mutations in metal transport or metal-binding proteins, or by the competition between metals for the binding sites (e.g., $\mathrm{Zn}$ and $\mathrm{Cu}$ ), can lead to an imbalance of essential trace metals or increased levels of non-essential trace elements $(17,18)$. 


\section{METALS AND THE AMYLOID PRECURSOR PROTEIN}

In $\mathrm{AD}$, metal imbalances occur in the brain $(3,19)$ as a result of the interactions between the metals and the critical proteins amyloid precursor protein (APP) and its products, amyloid beta (A $\beta$ ), and tau (Figure 1). APP, which is mainly expressed

A

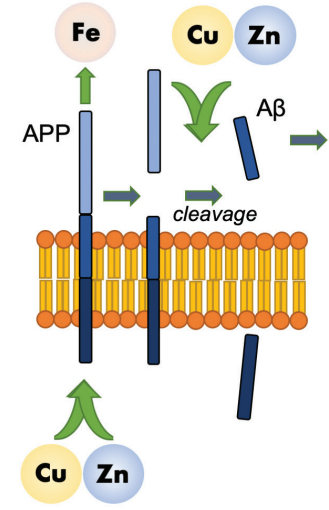

C
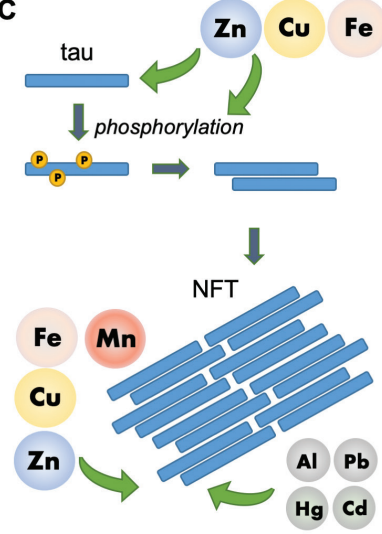

B
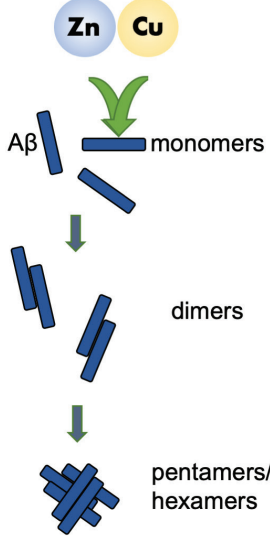

pentamers/

hexamers

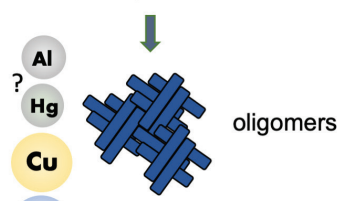

Zn

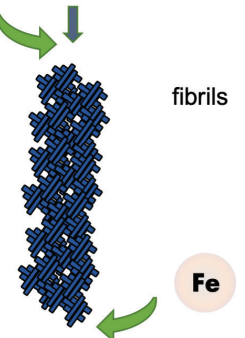

Figure 1. Trace metals interactions with APP, A $\beta$, and tau. (A) APP can be considered to act as a metalloprotein. It has two putative metal-binding sides with which it binds $\mathrm{Cu}$ and $\mathrm{Zn}$ ions. Fe is involved in the regulation of APP translation, and APP may mediate Fe export of neurons. A $\beta$ is derived from APP cleavage through $\beta$ - and $\gamma$-secretases. $\mathrm{Cu}$ and $\mathrm{Zn}$ indirectly influence $A \beta$ generation by interacting with all three secretases $(\alpha, \beta$, and $\gamma)$ involved in the cleavage of APP. (B) $A \beta$ directly binds $\mathrm{Zn}$ and $\mathrm{Cu}$ ions after enzymatic cleavage. Aggregation of $A \beta$ into insoluble fibrils is mediated by the interaction of $A \beta$ with $\mathrm{Zn}$ and $\mathrm{Cu}$. Chelation of $\mathrm{Zn}$ and $\mathrm{Cu}$ results in the enrichment of these ions in amyloid plaques. $\mathrm{A} \beta$ may also bind $\mathrm{Fe}$, and changes in $\mathrm{Fe}$ metabolism occur after the development plaques. Al has been detected in $\mathrm{A} \beta$ plaques suggesting an interaction of $\mathrm{Al}$ with $\mathrm{A} \beta$, and $\mathrm{Al}$ and $\mathrm{Hg}$ promote the accumulation of $\mathrm{A} \beta$ aggregates in vitro. (C) NFTs include trace metals such as $\mathrm{Zn}, \mathrm{Cu}, \mathrm{Fe}$, and $\mathrm{Mn}$, but also $\mathrm{Pb}, \mathrm{Cd}, \mathrm{Hg}$, and $\mathrm{Al}$ have been detected. Trace metals may promote tau hyperphosphorylation and induce tau aggregation. A direct interaction between $\mathrm{Zn}$ and tau has been reported. Similarly, a selective binding between tau and $\mathrm{Cu}$ was found. $\mathrm{Fe}$, as $\mathrm{Zn}$ and $\mathrm{Cu}$, interacts with some isoforms of tau. $\mathrm{Al}, \mathrm{Cd}, \mathrm{Pb}$, and $\mathrm{Hg}$ may not directly bind tau, but influence NFT formation through secondary processes. 
in the human brain, is involved in neuronal cell migration and neurite outgrowth (20). Copper binds to APP between residues 142 and 166 (21), playing essential roles in the structural stability of the protein, including folding stability and homodimerization, and expression levels (22). Zinc can also interact with APP using the site located between amino acid positions 170 and 188, regulating the homodimerization of $\operatorname{APP}(23,24)$. In addition, there is bidirectional regulation between iron and APP: iron can directly control APP translation, and APP levels control the export of iron in neurons (25). The A $\beta$ protein is derived from APP in the process of sequential proteolysis realized by $\beta$ and $\gamma$ - secretases. Insoluble amyloid fibrils of $A \beta$ are associated with metals like $\mathrm{Zn}, \mathrm{Cu}$, and $\mathrm{Fe}$ and represent a pathological feature of AD (26). Zinc plays a role in the stabilization of amyloid fibrils (27), binding to $A \beta$ at histidine (His) 13 and His6 sites (28). High zinc concentrations have been found at the level of senile plaques in postmortem tissues of patients affected by $\mathrm{AD}$ and in plaques of genetic $\mathrm{AD}$ mouse models, underlining the critical role of zinc in this process (26). Copper is considered to play a significant role in the neurotoxicity of $A \beta$. The monomeric $A \beta$ exhibits three highaffinity His Cu-binding sites: His6, His13, and His14. They are known to form a tetragonal complex with copper ions along with the Nterminal amino group and aspartate (29). In addition to this, copper is involved in the formation of $\beta$-sheet structures, the precursors of the toxic aggregates of the fibrillary form of $A \beta$. Several studies have shown that, in transgenic AD mouse models, $\mathrm{Cu}$ chelators could inhibit the accumulation of $A \beta(30,31)$. Iron also interacts with $A \beta$ at the binding sites of Asp1, Glu3, and the three His residues: His6, His13, and His14. The consequence of this interaction is the release of free radicals via Fenton chemistry (32). Other metals such as $\mathrm{Al}$ and $\mathrm{Hg}$ have been identified in $\mathrm{A} \beta$ plaques. While the role of $\mathrm{Al}$ in the $\mathrm{AD}$ pathology is still not clear, $\mathrm{Hg}$ promotes the accumulation of $A \beta$ deposits in vitro. $C d$ and $M n$ are also involved in increasing the $A \beta$ accumulation (33).

Another pathological hallmark of AD is hyperphosphorylation of the protein tau that leads to the formation of abnormal intracellular structures known as neurofibrillary tangles (NFTs). $\mathrm{Zn}, \mathrm{Cu}, \mathrm{Fe}, \mathrm{Mg}, \mathrm{Mn}, \mathrm{Pb}, \mathrm{Cd}, \mathrm{Hg}$, and $\mathrm{Al}$ have been found in these structures. Zinc interacts with tau using the serine (Ser) and proline (Pro) binding sites, using two cysteine (Cys) residues (C291 and C322), or threonine (Thr) and Pro sites (34). Zinc also interacts indirectly with tau, through the activation of kinase and phosphatase pathways (35). The importance of copper in the hyperphosphorylation of protein tau via the activation of the cyclindependent kinase (CDK)5/p25 complex is still controversial, although high levels of $\mathrm{Cu}$ have been reported in amyloid plaques and NFTs $(36,37)$. Iron $\left(\mathrm{Fe}^{3+}\right)$ is also reported to interact with NFTs through His residues (38). Like Cu, Fe can also indirectly contribute to hyperphosphorylation of tau, by activating the CDK5/ p25 complex and GSK-3 $\beta$ and MAP kinases (39).

The abundance of $A \beta$ and the formation of NFTs lead to an imbalance in trace metals that interact with tau and $A \beta$. It is both the interaction with the hallmark proteins of $\mathrm{AD}$ and the loss of trace metals in their physiological processes due to excessive binding by $\mathrm{A} \beta$ and tau that contributes to the pathogenesis of $\mathrm{AD}$. For example, in postmortem AD brains, increased Mn concentration, abnormal tau aggregation, and consequent hyperphosphorylation of tau caused by GSK-3 $\beta$ kinase, have been observed (40). The presence of toxic trace metals has also been reported in AD. For example, $\mathrm{Cd}$ is involved in the activation of GSK-3 $\beta$ kinase, 
inducing hyperphosphorylation of tau (41). Pb plays a role in the modulation of tau by regulating the activity of (CDK)5/p25 complex and GSK-3 $\beta$ kinase (42). To modify A $\beta$ aggregation, plaques, and the formation of NFTs, and to return essential trace metals to their effector proteins, balancing levels of trace metals is necessary and has been pursued as therapeutic strategy with some success in the past (43).

\section{NUTRITIONAL INTERVENTIONS}

The essential metals ( $\mathrm{Na}, \mathrm{K}, \mathrm{Ca}, \mathrm{Mg}$ ) and essential trace metals ( $\mathrm{Fe}, \mathrm{Zn}, \mathrm{Cu}, \mathrm{Mn}$, $\mathrm{Co}, \mathrm{Mo})$ are obtained almost exclusively from the diet. Trace metal deficiencies may affect the elderly $(44,45)$ and alter immune function (46). While some metaanalyses of studies analyzing the nutrient status of patients with AD found no significant differences in $\mathrm{Fe}, \mathrm{Zn}$, and $\mathrm{Cu}$ status $(47,48)$, more recent meta-analyses revealed significantly lower brain $\mathrm{Cu}$ (49) and serum Mn levels (50). However, subclinical trace metal deficiencies are hard to diagnose (51) and may not be detected in many individuals. Considering this, nutritional supplementation studies may provide additional insights. A systematic review found that the amount of caloric intake and type of diet may influence $\mathrm{AD}$ onset and progression (52). For example, reports show that a Mediterranean diet, which is naturally rich in metals, such as $\mathrm{Mg}, \mathrm{K}, \mathrm{Ca}$, and $\mathrm{Zn}$, (53), can have a neuroprotective effect that may be relevant to $\mathrm{AD}(54)$. In mouse models of $\mathrm{AD}$, zinc supplementation prevented cognitive deficits (55). In humans, despite case-control and postmortem studies showing decreased systemic Zn levels in AD patients $(47,56)$, studies investigating the effects of zinc supplementation provided inconclusive results. Zinc supplementation also reduces copper uptake due to an antagonistic relationship between the two metals (57). A diet low in $\mathrm{Cu}$ has been suggested as beneficial for AD (58-60), but a recent study does not support this hypothesis (61).

Trace metal homeostasis in AD is affected at cellular and sub-cellular levels in the brain and, thus, therapeutic strategies involving their manipulation may require more targeted approaches than dietary supplementation/restriction. However, trace metal supplementation in $\mathrm{AD}$ is still understudied. In addition to their direct effects on physiological processes in the brain, they may exert indirect effects through the microbiota composition of the gut (62). Regardless, maintaining adequate trace metal status will affect general health positively and may modify $\mathrm{AD}$ phenotypes, for example, by lowering pro-inflammatory responses and oxidative stress (63).

\section{TARGETED INTERVENTIONS: DELIVERY OF METAL-ATTENUATING COMPOUNDS}

Altered homeostasis of certain essential and non-essential trace metals can be the cause, as well as the consequence of AD pathology. Abnormal trace metal levels have been associated with neuroinflammation, mitochondrial dysfunction, oxidative stress, and protein aggregation (19). The AD hallmark proteins $A \beta$ and tau are metal-binding proteins. Therefore, metal chaperones 
and/or metal chelators may help modulate and counteract AD progression. Metal chaperones or metallochaperones are a class of compounds that shuttle metal ions to specific intracellular targets. In contrast, metal chelators or buffers function to exclude or deplete metals from discrete cellular compartments to limit biological or pathological interactions of essential metal ions. Cumulatively, these processes serve to maintain tight regulatory control over cellular metal ion homeostasis such that the intracellular concentration of freely available metal ions (like $\mathrm{Cu}$ and $\mathrm{Zn}$ ) is close to zero, and sufficient metals are available for crucial metal-binding proteins. Among the metalfocused interventions (Table 1), metal protein attenuating compounds

\section{TABLE 1 Metal interventions in preclinical and clinical trials}

\begin{tabular}{|c|c|c|c|c|}
\hline Drug & $\begin{array}{l}\text { Targeted } \\
\text { metal }\end{array}$ & Species & Effect of the drug & Reference \\
\hline $\begin{array}{l}\text { Clioquinol } \\
\text { (CQ) }\end{array}$ & $\mathrm{Fe}, \mathrm{Cu}, \mathrm{Zn}$ & Mouse: $\operatorname{Tg} 2576$ & $\begin{array}{l}\text { Reduction of sedimentable } A \beta(50 \%) \\
\text { plaques surface area and } A \beta \text { serum } \\
\text { levels and increase in } A \beta \text { soluble fraction }\end{array}$ & $(30)$ \\
\hline $\begin{array}{l}\text { Clioquinol } \\
\text { (CQ) }\end{array}$ & $\mathrm{Fe}, \mathrm{Cu}, \mathrm{Zn}$ & $\begin{array}{l}\text { Human: severe AD } \\
\text { patients }\end{array}$ & $\begin{array}{l}\text { Prevention of cognitive deterioration and } \\
\text { reduction of } A \beta \text { plasma levels }\end{array}$ & $(64)$ \\
\hline DP-109 & $\mathrm{Fe}, \mathrm{Cu}, \mathrm{Zn}$ & Mouse: $\operatorname{Tg} 2576$ & Reduction of $A \beta$ plaques and $C A A$ & $(66)$ \\
\hline PBT2 & $\mathrm{Fe}, \mathrm{Cu}, \mathrm{Zn}$ & $\begin{array}{l}\text { Mouse: APPswe/ } \\
\text { PS1 dE9 and } \\
\text { Tg2576 }\end{array}$ & $\begin{array}{l}\text { Decrease in soluble and insoluble } A \beta \\
\text { levels and plaques burden and } \\
\text { improvement in learning and memory } \\
\text { in the MWM }\end{array}$ & $(67)$ \\
\hline PBT2 & $\mathrm{Fe}, \mathrm{Cu}, \mathrm{Zn}$ & $\begin{array}{l}\text { Human: early/mild } \\
\text { AD patients }\end{array}$ & $\begin{array}{l}\text { Reduction of A } \beta \text { plasma and CSF levels } \\
\text { and improvement of executive tasks }\end{array}$ & $(70,71)$ \\
\hline DFO & $\mathrm{Al}, \mathrm{Fe}$ & $\begin{array}{l}\text { Human: } \mathrm{AD} \\
\text { patients }\end{array}$ & Reduction of mental deterioration & $(81)$ \\
\hline Ferelex-G & $\mathrm{Al}, \mathrm{Fe}$ & $\begin{array}{l}\text { Human: } \\
\text { postmortem } \\
\text { AD brain }\end{array}$ & $\begin{array}{l}\text { High Al/Fe removal bound to } \\
\text { hyperphosphorylated tau }\end{array}$ & (79) \\
\hline DFO & $\mathrm{Al}, \mathrm{Fe}$ & Mouse: APP/PS1 & $\begin{array}{l}\text { Reduction of } A \beta \text {, improvement in } \\
\text { learning and memory retention }\end{array}$ & $(82)$ \\
\hline TETA & $\mathrm{Cu}$ & $\begin{array}{l}\text { Mouse: APP/PS1 } \\
\text { and Tg2576 }\end{array}$ & $\begin{array}{l}\text { Reduction of A } \beta \text { deposition in APP/PS1 } \\
\text { but not in Tg2576 mice }\end{array}$ & (73) \\
\hline PDTC & $\mathrm{Cu}$ & Mouse: APP/PS1 & $\begin{array}{l}\text { Improvement of spatial learning but no } \\
\text { reduction of } A \beta \text { levels }\end{array}$ & $(75)$ \\
\hline Zn7MT3 & $\mathrm{Zn}$ & Mouse: $\operatorname{Tg} 2576$ & $\begin{array}{l}\text { Reduction of behavioral deficits, } A \beta \\
\text { aggregation, oxidative damage and } \\
\text { neurodegeneration }\end{array}$ & (83) \\
\hline XH1 & $\mathrm{Fe}, \mathrm{Cu}, \mathrm{Zn}$ & Mouse: APP/PS1 & Reduction of $A \beta$ load & $(87)$ \\
\hline
\end{tabular}

$\mathrm{AD}$, Alzheimer's disease; CAA, cerebral amyloid angiopathy; CSF, cerebrospinal fluid; MWM, Morris water maze. 
(MPACs) have been employed in both preclinical animal studies and human clinical trials. MPACs are metal chelators with a moderate affinity for metal ions and can cross the BBB. They correct abnormal metal interactions and have subtle effects on metal homeostasis. Therefore, they may limit metal binding to plaques, inhibit $\mathrm{Zn}$ and $\mathrm{Cu}$-induced oligomerization of $\mathrm{A} \beta$, and consequently reduce $A \beta$ aggregation and toxicity (64).

Clioquinol (CQ, 5-chloro-7-iodo-8-hydroxyquinoline, $\mathrm{MW}=305.5$ ) is a hydrophobic 8-hydroxy $(\mathrm{OH})$ quinoline derivative and an archetype of MAPCs. $\mathrm{CQ}$ freely crosses the BBB and is a moderate chelator of $\mathrm{Fe}, \mathrm{Cu}$, and $\mathrm{Zn}$. Additionally, with its ionophore activity, it works as a metal chaperon relocating metal ions into cells (65). Originally developed as an oral antiparasitic agent, CQ treatment significantly prevents the cognitive decline of patients with moderately severe AD, as demonstrated in a phase II clinical trial (64). The slowed cognitive decline was also accompanied by a transient decrease in $A \beta_{1-42}$ plasma levels. These results indicate the potential of $C Q$ and related compounds as treatments for $A D$ and have sparked further interest in MPACs. Also, in animal models of AD such as Tg2576 mice, chronic treatment with CQ can decrease A $\beta$ loads without adverse effects (30). Treated mice showed significant improvements in general behavior and neurotoxicity, in accordance with the results obtained in severely affected AD patients (64).

DP-109 is a diester derivative of BAPTA (1,2-bis(2-aminophenyloxy)ethane$\mathrm{N}, \mathrm{N}, \mathrm{N}^{\prime}, \mathrm{N}^{\prime}$-tetra acetic acid), a widely-used calcium chelator, that is able to cross the $\mathrm{BBB}$ and is designed to selectively chelate transition metals such as $\mathrm{Zn}, \mathrm{Cu}$, and $\mathrm{Fe}$ within membrane compartments (increased efficacy for divalent metals). Like CQ, prolonged administration of DP-109 to female Tg2576 mice markedly reduced the amyloid plaque load and the degree of cerebral amyloid angiopathy (CAA) (66).

PBT2 belongs to the second-generation MPACs and is a highly soluble derivative of $8-\mathrm{OH}$ quinoline that lacks iodine. With increased $\mathrm{BBB}$ permeability and ionophore activity compared to CQ, PBT2 reduced A $\beta$ levels and improved cognitive abilities in Tg2576 and APP/PS1 AD mouse models $(67,68)$. In these mice, both acute and chronic dosing resulted in a significant decrease in $A \beta$ plaque burden and interstitial fluid $A \beta$ levels, a significant increase in synaptophysin levels, and restoration of hippocampal dendritic spine density (69). In a 12-week phase-II clinical trial of early AD patients, PBT2 was also found to lower cerebrospinal fluid A $\beta_{42}$ concentrations and reverse frontal lobe functional deficits significantly, reducing executive dysfunction; however, no significant effects on cognition and memory were reported $(70,71)$.

The ionophore activity (the selective $A \beta$-metal-ion binding) of these compounds seems more promising than metal-chelation (metal-depletion) in counteracting AD pathology. While CQ and PBT2, possessing both features, are effective in reducing sedimented $A \beta$, triethylenetetramine (TETA), a classic hydrophilic $\mathrm{Cu}$ chelator, is not (72). TETA, a well-characterized anti-diabetic molecule, acts as a highly selective divalent copper $(\mathrm{Cu}(\mathrm{II}))$ chelator that prevents or reverses diabetic copper overload, thereby suppressing oxidative stress. Recent data showed that TETA disuccinate or trientine treatment also reduces A $\beta$ production and deposition in APP/PS1 mice but not in Tg2576 mice in the same experimental paradigm in which CQ was effective (73). Given the 
hybrid action of many of these compounds, the original proposed name shifted from MAPCs to "ionophores" and finally to "metallochaperones" (74). Other molecules with metal ion chaperone properties, like pyrrolidine dithiocarbamate (PDTC) and copper-bis(thiosemicarbazonoto) complexes, have also proved to ameliorate cognitive functions in $\mathrm{AD}$ mouse models, though they did not affect $\mathrm{A} \beta(75,76)$. On the contrary, D-penicillamine chelates $\mathrm{Cu}$ by forming a stable complex with thiol groups and allowing renal copper excretion. A clinical pilot study indicates that D-penicillamine can reduce oxidative stress, but not the clinical progression of AD (77).

While $\mathrm{Zn}, \mathrm{Fe}$, and $\mathrm{Cu}$ mainly bind to $\mathrm{A} \beta$ (78), $\mathrm{Al}$ and $\mathrm{Fe}$ accumulate and bind to hyperphosphorylated tau in neurons with NTFs (79). As Fe binds to both misfolded proteins, $\mathrm{Fe}$ is a potential target for chelation therapy. A 2-year long, single-blind clinical study showed that sustained intramuscular administration of desferrioxamine mesylate (DFO), an Al/Fe metal chelator, slows the clinical progression of $\mathrm{AD}$-associated dementia (80). Unfortunately, its hydrophilic nature and large molecular size limit its absorption across the gastrointestinal tract and prevent it from penetrating the BBB (80), inducing undesired side effects such as systemic metal depletion. All these features have prevented its final use in the clinics (81). More recent evidence showed that intranasal administration of DFO is accompanied by a reduction in A $\beta$ burden/ load as well as improved learning and memory abilities in APP/PS1 mice (82) confirming, again, the beneficial effects of this drug on AD pathology.

Other Fe chelators have been developed in the last 20 years. Feralex-G, for instance, showed enhanced chelating activity for Al/Fe associated with hyperphosphorylated tau compared to DFO (79).

Chelators such as TETA, penicillamine, and DFO are routinely used in the treatment of metal overload disorders, such as Wilson's disease. However, these molecules are hydrophilic and exert their effects by systemic depletion of metals and are poorly absorbed through the BBB with limited bioavailability. The efficacy of chelation therapy is still a matter of debate (74). Several metal-binding proteins are currently being tested as AD treatment. Metallothionein 3 (MT-3), a key regulator of metal homeostasis in the brain, has been found to decrease in $\mathrm{AD}$ patients. Intraventricular injection of Zn-loaded MT-3 (Zn/MT3) attenuates behavioral deficits, $A \beta$ aggregation, oxidative damage, and neurodegeneration in the Tg2576 AD mouse model. This drug allows the exchange of $\mathrm{A} \beta \mathrm{Cu}$ with $\mathrm{Zn}$ making A $\beta$ ROS inert (83).

Finally, another group of molecules has been characterized for their ability to modulate APP expression, leading to a novel therapeutic approach aimed at reducing the amyloidogenic process (84). A common feature of these molecules, to which the previously mentioned DFO belongs, is their ability to recognize an IRE stem-loop upstream to the start codon of the APP transcript at the APP-5'UTR region $(84,85)$. Like tetrathiomolybdate (TM) (a Cu chelator) and dimercaptopropanol (a $\mathrm{Pb}$ and $\mathrm{Hg}$ chelator), DFO reduces $\mathrm{A} \beta$ secretion and restrains the expression of APP holo-protein in vitro $(84,86)$. Similarly, XH1, a bifunctional compound capable of both APP binding and metal-chelation, was able to lower APP expression in the SH-SY5Y cell line and reduce A $\beta$ burden in APP/PS1 mice (87). Several other chelators with multifunctional properties with potential applications in AD treatment exist (88). However, so far, they have mainly been tested in vitro, and the beneficial effects they exert cannot all be attributed to their interaction with metals. 


\section{TABLE 2 Novel approaches in AD using DDSs}

\begin{tabular}{|c|c|c|c|}
\hline $\begin{array}{l}\text { Delivery } \\
\text { system }\end{array}$ & Function & Effect of the drug & Reference \\
\hline G7-Zn-NP & Zinc delivery & $\begin{array}{l}\text { Plaque size reduction and decrease in } \\
\text { pro-inflammatory cytokine release in vivo }\end{array}$ & (92) \\
\hline ZnONP & Zinc oxide delivery & $\begin{array}{l}\text { Dose-dependent inhibition of fibrillar amyloid } \\
\text { growth and } \beta \text {-sheet formation in vitro }\end{array}$ & (93) \\
\hline CQ-MSNP & CQ metal chelator & $\begin{array}{l}\text { Inhibition of } \mathrm{Cu}^{+}{ }^{+} \text {-induced } \mathrm{A} \beta 40 \text { aggregation } \\
\text { in vitro }\end{array}$ & (94) \\
\hline Nano-N2PY & Iron chelator & $\begin{array}{l}\text { Inhibition of } A \beta \text { aggregation in human cortex } \\
\text { in vitro }\end{array}$ & (95) \\
\hline
\end{tabular}

DDSs, drug delivery systems; AD, Alzheimer's disease.

\section{TARGETED INTERVENTIONS: DELIVERY OF TRACE METALS}

Although many studies support the efficacy of chelation therapy in vitro, the translation of metal chelators into clinical studies is currently limited due to their inability to cross the BBB easily: they are hydrophilic, and many are neurotoxic at high concentrations. The use of innovative drug delivery systems (DDSs) such as nanoparticles designed to overcome the BBB could be considered as a strategic approach in the prevention and treatment of neurological and neurodegenerative diseases such as AD (89-91). Several sustained-release nanocarriers have been studied for the treatment of AD; in particular, polymeric nanoparticles (NPs) allow a significant increase in bioavailability and effectiveness of the administered drugs. Although the efficacy and advantage of these systems have been supported by several experimental studies (Table 2), the translational efficacy is yet to be proven.

\section{CONCLUSION}

The role of trace metals in $\mathrm{AD}$ is complicated as they are involved in both pathological and physiological processes in the brain. In addition, trace metals such as zinc, which binds to more than $10 \%$ of proteins encoded in the human genome (96), regulate a plethora of processes whose effects are neither fully understood nor assessable in preclinical and clinical studies. Furthermore, levels of one trace metal affect the levels of other metals (19). Therefore, any therapeutic strategy targeting trace metal levels in AD needs to be specific in terms of drug delivery and consider its effect on the concentration of a particular metal. Preclinical and clinical studies attempting to manipulate trace metals, although not entirely successful, were among the most promising approaches for the treatment for $\mathrm{AD}$. Metal chelation and chaperoning successfully reduced $\mathrm{A} \beta$ 


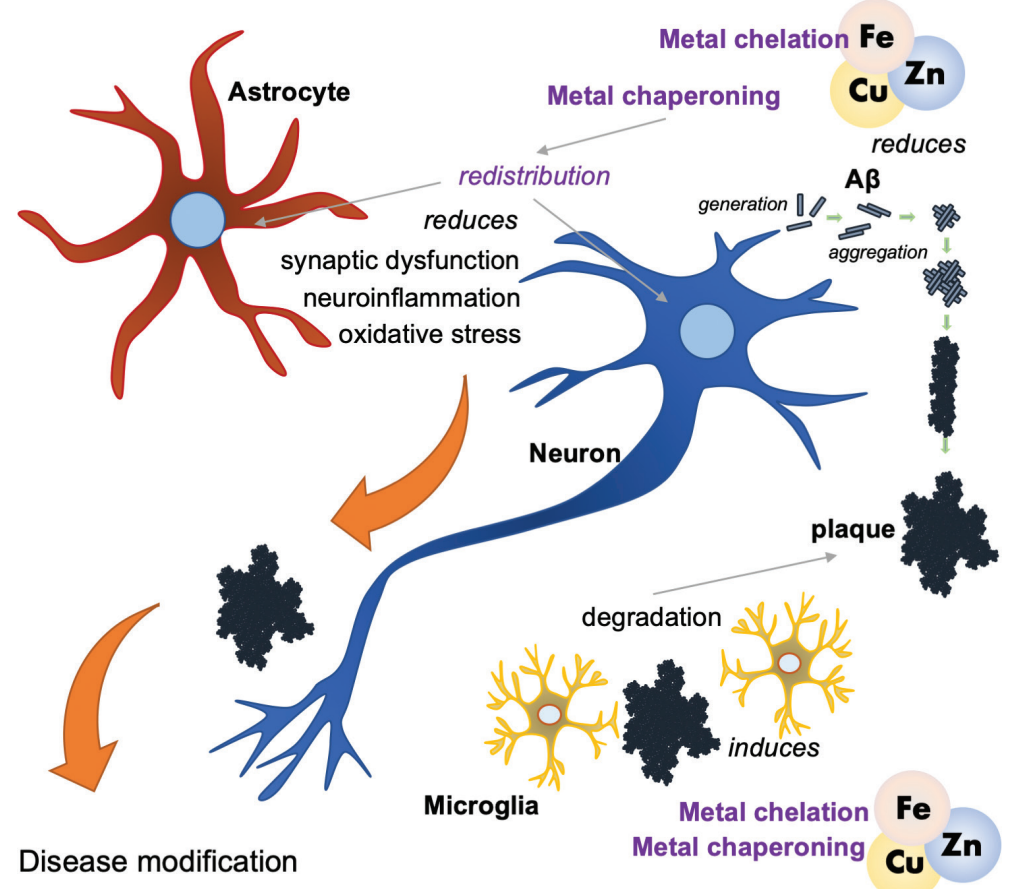

Figure 2. Targeting trace metals as therapeutic strategy in AD. Metal chelators and ionophores can prevent metal binding to $A \beta$, inhibit oligomerization of $A \beta$, and consequently reduce its aggregation and toxicity. Altering metal homeostasis by depletion, delivery, and chaperoning was reported to decrease $A \beta$ plaque burden and interstitial fluid $A \beta$ levels, positively affect synaptic spine density, and suppress oxidative stress. Zinc delivery further reduces inflammation, while iron chelation modifies tau phosphorylation, and APP expression.

generation and aggregation, synaptic dysfunction, neuroinflammation, oxidative stress, and induced degradation of senile plaques (Figure 2). In addition, effects on cognitive abilities were observed in some studies. To further develop treatment strategies targeting metal homeostasis, it is necessary to clearly understand the role of trace metals in $\mathrm{AD}$. It is important to explore the role of trace metals, such as zinc, in physiological processes that could be exploited as therapeutic targets apart from A $\beta$ aggregates, such as synaptic plasticity mediated by zinc-dependent SHANK proteins (97) or reducing excitotoxicity and $A \beta$ burden by zinc-binding S100B proteins (98-101). A re-distribution and balancing of metals may be necessary between neurons, astrocytes, and microglial cells to optimize effects on synapses and inflammatory processes. This could be achieved by targeted delivery of trace metals to A $\beta$ aggregates and NFTs. To this end, novel compounds, combinations of novel metal chelators and chaperones, and novel delivery platforms will be needed.

Conflict of Interest: The authors declare no potential conflict of interest with respect to research, authorship and/or publication of this chapter. 
Copyright and Permission Statement: To the best of our knowledge, the materials included in this chapter do not violate copyright laws. All original sources have been appropriately acknowledged and/or referenced. Where relevant, appropriate permissions have been obtained from the original copyright holder(s).

\section{REFERENCES}

1. Hyman BT, Trojanowski JQ. Consensus recommendations for the postmortem diagnosis of Alzheimer disease from the National Institute on Aging and the Reagan Institute Working Group on diagnostic criteria for the neuropathological assessment of Alzheimer disease. J Neuropathol Exp Neurol. 1997;56(10):1095-7. http://dx.doi.org/10.1097/00005072-199710000-00002

2. Hyman BT, Phelps CH, Beach TG, Bigio EH, Cairns NJ, Carrillo MC, et al. National Institute on Aging-Alzheimer's Association guidelines for the neuropathologic assessment of Alzheimer's disease. Alzheimers Dement. 2012;8(1):1-13. http://dx.doi.org/10.1016/j.jalz.2011.10.007

3. Wang P, Wang ZY. Metal ions influx is a double edged sword for the pathogenesis of Alzheimer's disease. Ageing Res Rev. 2017;35:265-90. http://dx.doi.org/10.1016/j.arr.2016.10.003

4. Yehuda S, Youdim MB. Brain iron: A lesson from animal models. Am J Clin Nutr 1989;50(3 Suppl.): 618-25; discussion 625-9. http://dx.doi.org/10.1093/ajcn/50.3.618

5. Eisenstein RS. Iron regulatory proteins and the molecular control of mammalian iron metabolism. Annu Rev Nutr. 2000;20:627-62. http://dx.doi.org/10.1146/annurev.nutr.20.1.627

6. Clardy SL, Wang X, Zhao W, Liu W, Chase GA, Beard JL, et al. Acute and chronic effects of developmental iron deficiency on mRNA expression patterns in the brain. J Neural Transm Suppl. 2006;71:173-96. http://dx.doi.org/10.1007/978-3-211-33328-0_19

7. Kwik-Uribe CL, Gietzen D, German JB, Golub MS, Keen CL. Chronic marginal iron intakes during early development in mice result in persistent changes in dopamine metabolism and myelin composition. J Nutr. 2000;130(11):2821-30. http://dx.doi.org/10.1093/jn/130.11.2821

8. Dallman PR. Biochemical basis for the manifestations of iron deficiency. Annu Rev Nutr. 1986;6: 13-40. http://dx.doi.org/10.1146/annurev.nu.06.070186.000305

9. De Benedictis CA, Raab A, Ducie E, Howley S, Feldmann J, Grabrucker AM. Concentrations of essential trace metals in the brain of animal species - A comparative study. Brain Sci. 2020;10(7). http://dx.doi.org/10.3390/brainscil0070460

10. Takeda A. Zinc homeostasis and functions of zinc in the brain. Biometals. 2001;14(3-4):343-51. http://dx.doi.org/10.1023/a:1012982123386

11. Fukada T, Yamasaki S, Nishida K, Murakami M, Hirano T. Zinc homeostasis and signaling in health and diseases: Zinc signaling. J Biol Inorg Chem. 2011;16(7):1123-34. http://dx.doi.org/10.1007/ s00775-011-0797-4

12. Levenson CW, Morris D. Zinc and neurogenesis: Making new neurons from development to adulthood. Adv Nutr. 2011;2(2):96-100. http://dx.doi.org/10.3945/an.110.000174

13. Tapiero H, Tew KD. Trace elements in human physiology and pathology: Zinc and metallothioneins. Biomed Pharmacother. 2003;57(9):399-411. http://dx.doi.org/10.1016/s07533322(03)00081-7

14. Prasad AS. Clinical, immunological, anti-inflammatory and antioxidant roles of zinc. Exp Gerontol 2008;43(5):370-7. http://dx.doi.org/10.1016/j.exger.2007.10.013

15. Peña MM, Lee J, Thiele DJ. A delicate balance: Homeostatic control of copper uptake and distribution. J Nutr 1999;129(7):1251-60. http://dx.doi.org/10.1093/jn/129.7.1251

16. Horning KJ, Caito SW, Tipps KG, Bowman AB, Aschner M. Manganese is essential for neuronal health. Annu Rev Nutr. 2015;35:71-108. http://dx.doi.org/10.1146/annurev-nutr-071714-034419

17. Zheng W, Monnot AD. Regulation of brain iron and copper homeostasis by brain barrier systems: Implication in neurodegenerative diseases. Pharmacol Ther 2012;133(2):177-88. http://dx.doi. org/10.1016/j.pharmthera.2011.10.006 
18. Sensi SL, Granzotto A, Siotto M, Squitti R. Copper and zinc dysregulation in Alzheimer's disease. Trends Pharmacol Sci. 2018;39(12):1049-63. http://dx.doi.org/10.1016/j.tips.2018.10.001

19. Pfaender S, Grabrucker AM. Characterization of biometal profiles in neurological disorders. Metallomics. 2014;6(5):960-77. http://dx.doi.org/10.1039/c4mt00008k

20. Walsh DM, Minogue AM, Sala Frigerio C, Fadeeva JV, Wasco W, Selkoe DJ. The APP family of proteins: Similarities and differences. Biochem Soc Trans. 2007;35(Pt2):416-20. http://dx.doi.org/10.1042/ BST0350416

21. Barnham KJ, McKinstry WJ, Multhaup G, Galatis D, Morton CJ, Curtain CC, et al. Structure of the Alzheimer's disease amyloid precursor protein copper binding domain. A regulator of neuronal copper homeostasis. J Biol Chem. 2003;278(19):17401-7. http://dx.doi.org/10.1074/jbc.M300629200

22. Bellingham SA, Lahiri DK, Maloney B, La Fontaine S, Multhaup G, Camakaris J. Copper depletion down-regulates expression of the Alzheimer's disease amyloid-beta precursor protein gene. J Biol Chem. 2004;279(19):20378-86. http://dx.doi.org/10.1074/jbc.M400805200

23. Bush AI, Multhaup G, Moir RD, Williamson TG, Small DH, Rumble B, et al. A novel zinc(II) binding site modulates the function of the beta A4 amyloid protein precursor of Alzheimer's disease. J Biol Chem. 1993;268(22):16109-12.

24. Bush AI, Pettingell WH, de Paradis M, Tanzi RE, Wasco W. The amyloid beta-protein precursor and its mammalian homologues. Evidence for a zinc-modulated heparin-binding superfamily. J Biol Chem. 1994;269(43):26618-21.

25. Venti A, Giordano T, Eder P, Bush AI, Lahiri DK, Greig NH, et al. The integrated role of desferrioxamine and phenserine targeted to an iron-responsive element in the APP-mRNA 5'-untranslated region. Ann N Y Acad Sci. 2004;1035:34-48. http://dx.doi.org/10.1196/annals.1332.003

26. Lovell MA, Robertson JD, Teesdale WJ, Campbell JL, Markesbery WR. Copper, iron and zinc in Alzheimer's disease senile plaques. J Neurol Sci. 1998;158(1):47-52. http://dx.doi.org/10.1016/ s0022-510x(98)00092-6

27. Cuajungco MP, Lees GJ. Zinc and Alzheimer's disease: Is there a direct link? Brain Res Brain Res Rev. 1997;23(3):219-36. http://dx.doi.org/10.1016/s0165-0173(97)00002-7

28. Bush AI, Pettingell WH, Multhaup G, Paradis MD, Vonsattel JP, Gusella JF, et al. Rapid induction of Alzheimer A beta amyloid formation by zinc. Science. 1994;265(5177):1464-7. http://dx.doi. org/10.1126/science.8073293

29. Minicozzi V, Stellato F, Comai M, Dalla Serra M, Potrich C, Meyer-Klaucke W, et al. Identifying the minimal copper- and zinc-binding site sequence in amyloid-beta peptides. J Biol Chem. 2008;283(16):10784-92. http://dx.doi.org/10.1074/jbc.M707109200

30. Cherny RA, Atwood CS, Xilinas ME, Gray DN, Jones WD, McLean CA, et al. Treatment with a copper-zinc chelator markedly and rapidly inhibits beta-amyloid accumulation in Alzheimer's disease transgenic mice. Neuron. 2001;30(3):665-76. http://dx.doi.org/10.1016/s0896-6273(01)00317-8

31. Bush AI. Metal complexing agents as therapies for Alzheimer's disease. Neurobiol Aging. 2002;23(6):1031-8. http://dx.doi.org/10.1016/s0197-4580(02)00120-3

32. Telling ND, Everett J, Collingwood JF, Dobson J, van der Laan G, Gallagher JJ, et al. Iron biochemistry is correlated with amyloid plaque morphology in an Established Mouse Model of Alzheimer's disease. Cell Chem Biol. 2017;24(10):1205-15.e3. http://dx.doi.org/10.1016/j.chembiol.2017.07.014

33. De Benedictis CA, Viella A, Grabrucker AM. The role of trace metals in Alzehimer's disease. In: Wisniewski T, editor. Alzheimer's disease. Brisbane: Codon Publications; 2019. Chapter 6. http:// dx.doi.org/10.15586/alzehimersdisease.2019.ch6

34. Mo ZY, Zhu YZ, Zhu HL, Fan JB, Chen J, Liang Y. Low micromolar zinc accelerates the fibrillization of human tau via bridging of Cys-291 and Cys-322. J Biol Chem. 2009;284(50):34648-57. http:// dx.doi.org/10.1074/jbc.M109.058883

35. Kim I, Park EJ, Seo J, Ko SJ, Lee J, Kim CH. Zinc stimulates tau S214 phosphorylation by the activation of Raf/mitogen-activated protein kinase-kinase/extracellular signalregulated kinase pathway. Neuroreport. 2011;22(16):839-44. http://dx.doi.org/10.1097/ WNR.Ob013e32834c0a2d

36. Sayre LM, Perry G, Atwood CS, Smith MA. The role of metals in neurodegenerative diseases. Cell Mol Biol (Noisy-le-grand). 2000;46(4):731-41. 
37. Kitazawa M, Cheng D, Laferla FM. Chronic copper exposure exacerbates both amyloid and tau pathology and selectively dysregulates cdk5 in a mouse model of AD. J Neurochem. 2009;108(6): 1550-60. http://dx.doi.org/10.1111/j.1471-4159.2009.05901.x

38. Smith MA, Harris PL, Sayre LM, Perry G. Iron accumulation in Alzheimer disease is a source of redoxgenerated free radicals. Proc Natl Acad Sci U S A. 1997;94(18):9866-8. http://dx.doi.org/10.1073/ pnas.94.18.9866

39. Guo C, Wang P, Zhong ML, Wang T, Huang XS, Li JY, et al. Deferoxamine inhibits iron induced hippocampal tau phosphorylation in the Alzheimer transgenic mouse brain. Neurochem Int. 2013;62(2):165-72. http://dx.doi.org/10.1016/j.neuint.2012.12.005

40. Cai T, Che H, Yao T, Chen Y, Huang C, Zhang W, et al. Manganese induces tau hyperphosphorylation through the activation of ERK MAPK pathway in PC12 cells. Toxicol Sci. 2011;119(1):169-77. http:// dx.doi.org/10.1093/toxsci/kfq308

41. Del Pino J, Zeballos G, Anadón MJ, Moyano P, Díaz MJ, García JM, et al. Cadmium-induced cell death of basal forebrain cholinergic neurons mediated by muscarinic Ml receptor blockade, increase in GSK-3 $\beta$ enzyme, $\beta$-amyloid and tau protein levels. Arch Toxicol. 2016;90(5):1081-92. http://dx.doi. org/10.1007/s00204-015-1540-7

42. Bihaqi SW, Bahmani A, Adem A, Zawia NH. Infantile postnatal exposure to lead $(\mathrm{Pb})$ enhances tau expression in the cerebral cortex of aged mice: Relevance to AD. Neurotoxicology. 2014;44:114-20. http://dx.doi.org/10.1016/j.neuro.2014.06.008

43. Yang GJ, Liu H, Ma DL, Leung CH. Rebalancing metal dyshomeostasis for Alzheimer's disease therapy. J Biol Inorg Chem. 2019;24(8):1159-70. http://dx.doi.org/10.1007/s00775-019-01712-y

44. Morley JE. Nutritional problems in the elderly. Bol Asoc Med P R. 1987;79(12):505-7.

45. Prasad AS, Fitzgerald JT, Hess JW, Kaplan J, Pelen F, Dardenne M. Zinc deficiency in elderly patients. Nutrition. 1993;9(3):218-24.

46. Haase H, Mocchegiani E, Rink L. Correlation between zinc status and immune function in the elderly. Biogerontology. 2006;7(5-6):421-8. http://dx.doi.org/10.1007/s10522-006-9057-3

47. Loef M, von Stillfried N, Walach H. Zinc diet and Alzheimer's disease: A systematic review. Nutr Neurosci. 2012;15(5):2-12. http://dx.doi.org/10.1179/1476830512Y.0000000010

48. Lopes da Silva S, Vellas B, Elemans S, Luchsinger J, Kamphuis P, Yaffe K, et al. Plasma nutrient status of patients with Alzheimer's disease: Systematic review and meta-analysis. Alzheimers Dement. 2014;10(4):485-502. http://dx.doi.org/10.1016/j.jalz.2013.05.1771

49. de Wilde MC, Vellas B, Girault E, Yavuz AC, Sijben JW. Lower brain and blood nutrient status in Alzheimer's disease: Results from meta-analyses. Alzheimers Dement (NY). 2017;3(3):416-31. http:// dx.doi.org/10.1016/j.trci.2017.06.002

50. Du K, Liu M, Pan Y, Zhong X, Wei M. Association of serum manganese levels with Alzheimer's disease and mild cognitive impairment: A systematic review and meta-analysis. Nutrients. 2017;9(3):231. http://dx.doi.org/10.3390/nu9030231

51. Roohani N, Hurrell R, Kelishadi R, Schulin R. Zinc and its importance for human health: An integrative review. J Res Med Sci. 2013;18(2):144-57.

52. Burgener SC, Buettner L, Coen Buckwalter K, Beattie E, Bossen AL, Fick DM, et al. Evidence supporting nutritional interventions for persons in early stage Alzheimer's disease (AD). J Nutr Health Aging. 2008;12(1):18-21. http://dx.doi.org/10.1007/BF02982159

53. Knight A, Bryan J, Murphy K. Is the Mediterranean diet a feasible approach to preserving cognitive function and reducing risk of dementia for older adults in Western countries? New insights and future directions. Ageing Res Rev. 2016;25:85-101. http://dx.doi.org/10.1016/j.arr.2015.10.005

54. Solfrizzi V, Frisardi V, Seripa D, Logroscino G, Imbimbo BP, D'Onofrio G, et al. Mediterranean diet in predementia and dementia syndromes. Curr Alzheimer Res. 2011;8(5):520-42. http://dx.doi. org/10.2174/156720511796391809

55. Corona C, Masciopinto F, Silvestri E, Viscovo AD, Lattanzio R, Sorda RL, et al. Dietary zinc supplementation of 3xTg-AD mice increases BDNF levels and prevents cognitive deficits as well as mitochondrial dysfunction. Cell Death Dis. 2010;1:e91. http://dx.doi.org/10.1038/cddis.2010.73

56. Brewer GJ, Kanzer SH, Zimmerman EA, Molho ES, Celmins DF, Heckman SM, et al. Subclinical zinc deficiency in Alzheimer's disease and Parkinson's disease. Am J Alzheimers Dis Other Demen 2010;25(7):572-5. http://dx.doi.org/10.1177/1533317510382283 
57. Brewer GJ. Copper excess, zinc deficiency, and cognition loss in Alzheimer's disease. Biofactors. 2012;38(2):107-13. http://dx.doi.org/10.1002/biof.1005

58. Brewer GJ. The risks of copper toxicity contributing to cognitive decline in the aging population and to Alzheimer's disease. J Am Coll Nutr. 2009;28(3):238-42. http://dx.doi.org/10.1080/07315724. 2009.10719777

59. Squitti R, Siotto M, Polimanti R. Low-copper diet as a preventive strategy for Alzheimer's disease. Neurobiol Aging. 2014;35(Suppl. 2):40-50. http://dx.doi.org/10.1016/j.neurobiolaging.2014.02.031

60. Hsu HW, Bondy SC, Kitazawa M. Environmental and dietary exposure to copper and its cellular mechanisms linking to Alzheimer's disease. Toxicol Sci. 2018;163(2):338-45. http://dx.doi. org/10.1093/toxsci/kfy025

61. Solioz M. Low copper-2 intake in Switzerland does not result in lower incidence of Alzheimer's disease and contradicts the Copper-2 Hypothesis. Exp Biol Med (Maywood). 2020;245(3):177-9. http://dx.doi.org/10.1177/1535370219899898

62. Sauer AK, Grabrucker AM. Zinc deficiency during pregnancy leads to altered microbiome and elevated inflammatory markers in mice. Front Neurosci. 2019;13:1295. http://dx.doi.org/10.3389/ fnins.2019.01295

63. Prasad AS. Zinc: An antioxidant and anti-inflammatory agent: Role of zinc in degenerative disorders of aging. J Trace Elem Med Biol. 2014;28(4):364-71. http://dx.doi.org/10.1016/j.jtemb.2014.07.019

64. Ritchie CW, Bush AI, Mackinnon A, Macfarlane S, Mastwyk M, MacGregor L, et al. Metal-protein attenuation with iodochlorhydroxyquin (clioquinol) targeting Abeta amyloid deposition and toxicity in Alzheimer disease: A pilot phase 2 clinical trial. Arch Neurol. 2003;60(12):1685-91. http://dx.doi. org/10.1001/archneur.60.12.1685

65. Park MH, Lee SJ, Byun HR, Kim Y, Oh YJ, Koh JY, et al. Clioquinol induces autophagy in cultured astrocytes and neurons by acting as a zinc ionophore. Neurobiol Dis. 2011;42(3):242-51. http:// dx.doi.org/10.1016/j.nbd.2011.01.009

66. Lee JY, Friedman JE, Angel I, Kozak A, Koh JY. The lipophilic metal chelator DP-109 reduces amyloid pathology in brains of human beta-amyloid precursor protein transgenic mice. Neurobiol Aging. 2004;25(10):1315-21. http://dx.doi.org/10.1016/j.neurobiolaging.2004.01.005

67. Adlard PA, Cherny RA, Finkelstein DI, Gautier E, Robb E, Cortes M, et al. Rapid restoration of cognition in Alzheimer's transgenic mice with 8-hydroxy quinoline analogs is associated with decreased interstitial Abeta. Neuron. 2008;59(1):43-55. http://dx.doi.org/10.1016/j.neuron.2008.06.018

68. Crouch PJ, Savva MS, Hung LW, Donnelly PS, Mot AI, Parker SJ, et al. The Alzheimer's therapeutic PBT2 promotes amyloid- $\beta$ degradation and GSK3 phosphorylation via a metal chaperone activity. J Neurochem. 2011;119(1):220-30. http://dx.doi.org/10.1111/j.1471-4159.2011.07402.x

69. Adlard PA, Bush AI. Metal chaperones: A holistic approach to the treatment of Alzheimer's disease. Front Psychiatry. 2012;3:15. http://dx.doi.org/10.3389/fpsyt.2012.00015

70. Lannfelt L, Blennow K, Zetterberg H, Batsman S, Ames D, Harrison J, et al. Safety, efficacy, and biomarker findings of PBT2 in targeting Abeta as a modifying therapy for Alzheimer's disease: A phase IIa, double-blind, randomised, placebo-controlled trial. Lancet Neurol. 2008;7(9):779-86. http:// dx.doi.org/10.1016/S1474-4422(08)70167-4

71. Faux NG, Ritchie CW, Gunn A, Rembach A, Tsatsanis A, Bedo J, et al. PBT2 rapidly improves cognition in Alzheimer's disease: Additional phase II analyses. J Alzheimers Dis. 2010;20(2):509-16. http://dx.doi.org/10.3233/JAD-2010-1390

72. Bush AI. The metallobiology of Alzheimer's disease. Trends Neurosci. 2003;26(4):207-14. http:// dx.doi.org/10.1016/S0166-2236(03)00067-5

73. Wang CY, Xie JW, Xu Y, Wang T, Cai JH, Wang X, et al. Trientine reduces BACEl activity and mitigates amyloidosis via the AGE/RAGE/NF-kB pathway in a transgenic mouse model of Alzheimer's disease. Antioxid Redox Signal. 2013;19(17):2024-39. http://dx.doi.org/10.1089/ars.2012.5158

74. Drew SC. The case for abandoning therapeutic chelation of copper ions in Alzheimer's disease. Front Neurosci. 2017;11:317. http://dx.doi.org/10.3389/fnins.2017.00317

75. Malm TM, Iivonen H, Goldsteins G, Keksa-Goldsteine V, Ahtoniemi T, Kanninen K, et al. Pyrrolidine dithiocarbamate activates Akt and improves spatial learning in APP/PS1 mice without affecting beta-amyloid burden. J Neurosci. 2007;27(14):3712-21. http://dx.doi.org/10.1523/ JNEUROSCI.0059-07.2007 
76. Crouch PJ, Hung LW, Adlard PA, Cortes M, Lal V, Filiz G, et al. Increasing Cu bioavailability inhibits Abeta oligomers and tau phosphorylation. Proc Natl Acad Sci U S A. 2009;106(2):381-6. http:// dx.doi.org/10.1073/pnas.0809057106

77. Squitti R, Rossini PM, Cassetta E, Moffa F, Pasqualetti P, Cortesi M, et al. d-penicillamine reduces serum oxidative stress in Alzheimer's disease patients. Eur J Clin Invest. 2002;32(1):51-9. http:// dx.doi.org/10.1046/j.1365-2362.2002.00933.x

78. Hane F, Tran G, Attwood SJ, Leonenko Z. Cu(2+) affects amyloid- $\beta$ (1-42) aggregation by increasing peptide-peptide binding forces. PLoS One 2013;8(3):e59005. http://dx.doi.org/10.1371/journal. pone.0059005

79. Shin RW, Kruck TP, Murayama H, Kitamoto T. A novel trivalent cation chelator Feralex dissociates binding of aluminum and iron associated with hyperphosphorylated tau of Alzheimer's disease. Brain Res. 2003;961(1):139-46. http://dx.doi.org/10.1016/s0006-8993(02)03893-3

80. Aouad F, Florence A, Zhang Y, Collins F, Henry C, Ward RJ, et al. Evaluation of new iron chelators and their therapeutic potential. Inorganica Chimica Acta. 2002;339:470-80. http://dx.doi.org/10.1016/ S0020-1693(02)01040-X

81. Crapper McLachlan DR, Dalton AJ, Kruck TP, Bell MY, Smith WL, Kalow W, et al. Intramuscular desferrioxamine in patients with Alzheimer's disease. Lancet. 1991;337(8753):1304-8. http://dx.doi. org/10.1016/0140-6736(91)92978-b

82. Guo C, Wang T, Zheng W, Shan ZY, Teng WP, Wang ZY. Intranasal deferoxamine reverses ironinduced memory deficits and inhibits amyloidogenic APP processing in a transgenic mouse model of Alzheimer's disease. Neurobiol Aging. 2013;34(2):562-75. http://dx.doi.org/10.1016/j. neurobiolaging.2012.05.009

83. Xu W, Xu Q, Cheng H, Tan X. The efficacy and pharmacological mechanism of Zn7MT3 to protect against Alzheimer's disease. Sci Rep. 2017;7(1):13763. http://dx.doi.org/10.1038/s41598-017-12800-x

84. Rogers JT, Lahiri DK. Metal and inflammatory targets for Alzheimer's disease. Curr Drug Targets. 2004;5(6):535-51. http://dx.doi.org/10.2174/1389450043345272

85. Bandyopadhyay S, Huang X, Cho H, Greig NH, Youdim MB, Rogers JT. Metal specificity of an ironresponsive element in Alzheimer's APP mRNA 5'untranslated region, tolerance of SH-SY5Y and H4 neural cells to desferrioxamine, clioquinol, VK-28, and a piperazine chelator. J Neural Transm Suppl. 2006;71:237-47. http://dx.doi.org/10.1007/978-3-211-33328-0_25

86. Payton S, Cahill CM, Randall JD, Gullans SR, Rogers JT. Drug discovery targeted to the Alzheimer's APP mRNA 5'-untranslated region: The action of paroxetine and dimercaptopropanol. J Mol Neurosci. 2003;20(3):267-75. http://dx.doi.org/10.1385/JMN:20:3:267

87. Dedeoglu A, Cormier K, Payton S, Tseitlin KA, Kremsky JN, Lai L, et al. Preliminary studies of a novel bifunctional metal chelator targeting Alzheimer's amyloidogenesis. Exp Gerontol. 2004;39 (11-12):1641-9. http://dx.doi.org/10.1016/j.exger.2004.08.016

88. Nuñez MT, Chana-Cuevas P. New perspectives in iron chelation therapy for the treatment of neurodegenerative diseases. Pharmaceuticals (Basel). 2018;11(4):109. http://dx.doi.org/10.3390/ ph11040109

89. Georganopoulou DG, Chang L, Nam JM, Thaxton CS, Mufson EJ, Klein WL, et al. Nanoparticle-based detection in cerebral spinal fluid of a soluble pathogenic biomarker for Alzheimer's disease. Proc Natl Acad Sci U S A. 2005;102(7):2273-6. http://dx.doi.org/10.1073/pnas.0409336102

90. Andrieux K, Couvreur P. Nanomedicine as a promising approach for the treatment and diagnosis of brain diseases: The example of Alzheimer's disease. Ann Pharm Fr. 2013;71(4):225-33. http://dx.doi. org/10.1016/j.pharma.2013.04.001

91. Brambilla D, Verpillot R, Le Droumaguet B, Nicolas J, Taverna M, Kóňa J, et al. PEGylated nanoparticles bind to and alter amyloid-beta peptide conformation: Toward engineering of functional nanomedicines for Alzheimer's disease. ACS Nano. 2012;6(7):5897-908. http://dx.doi.org/10.1021/ $\mathrm{nn} 300489 \mathrm{k}$

92. Vilella A, Belletti D, Sauer AK, Hagmeyer S, Sarowar T, Masoni M, et al. Reduced plaque size and inflammation in the APP23 mouse model for Alzheimer's disease after chronic application of polymeric nanoparticles for CNS targeted zinc delivery. J Trace Elem Med Biol. 2018;49:210-21. http://dx.doi. org/10.1016/j.jtemb.2017.12.006 
93. Ban DK, Paul S. Nano zinc oxide inhibits fibrillar growth and uppresses cellular toxicity of lysozyme amyloid. ACS Appl Mater Interfaces. 2016;8(46):31587-601. http://dx.doi.org/10.1021/ acsami.6b11549

94. Yang L, Yin T, Liu Y, Sun J, Zhou Y, Liu J. Gold nanoparticle-capped mesoporous silica-based H2O2responsive controlled release system for Alzheimer's disease treatment. Acta Biomater. 2016;46: 177-90. http://dx.doi.org/10.1016/j.actbio.2016.09.010

95. Liu G, Men P, Kudo W, Perry G, Smith MA. Nanoparticle-chelator conjugates as inhibitors of amyloidbeta aggregation and neurotoxicity: A novel therapeutic approach for Alzheimer disease. Neurosci Lett. 2009;455(3):187-90. http://dx.doi.org/10.1016/j.neulet.2009.03.064

96. Andreini C, Banci L, Bertini I, Rosato A. Counting the zinc-proteins encoded in the human genome. J Proteome Res. 2006;5(1):196-201. http://dx.doi.org/10.1021/pr05036lj

97. Grabrucker AM, Schmeisser MJ, Udvardi PT, Arons M, Schoen M, Woodling NS, et al. Amyloid beta protein-induced zinc sequestration leads to synaptic loss via dysregulation of the ProSAP2/Shank3 scaffold. Mol Neurodegener. 2011;6:65. http://dx.doi.org/10.1186/1750-1326-6-65

98. Cristóvão JS, Figueira AJ, Carapeto A, Rodrigues MS, Cardoso I, Gomes CM. The S100B alarmin is a dual-function chaperone suppressing $A \beta$ oligomerization through combined zinc chelation and inhibition of protein aggregation. ACS Chem Neurosci. 2020; 11(17):2753-60. http://dx.doi. org/10.1021/acschemneuro.0c00392

99. Cristóvão JS, Morris VK, Cardoso I, Leal SS, Martínez J, Botelho HM, et al. The neuronal S100B protein is a calcium-tuned suppressor of amyloid- $\beta$ aggregation. Sci Adv 2018;4(6):eaaq1702. http:// dx.doi.org/10.1126/sciadv.aaq1702

100. Hagmeyer S, Cristóvão JS, Mulvihill JJE, Boeckers TM, Gomes CM, Grabrucker AM. Zinc binding to $\mathrm{S} 100 \mathrm{~B}$ affords regulation of trace metal homeostasis and excitotoxicity in the brain. Front Mol Neurosci. 2017;10:456. http://dx.doi.org/10.3389/fnmol.2017.00456

101. Hagmeyer S, Romão MA, Cristóvão JS, Vilella A, Zoli M, Gomes CM, et al. Distribution and relative abundance of S100 proteins in the brain of the APP23 Alzheimer's disease model mice. Front Neurosci. 2019;13:640. http://dx.doi.org/10.3389/fnins.2019.00640 